\title{
Pluripotent stem cells to hepatocytes, the journey so far (Review)
}

\author{
ANWAR A. PALAKKAN, JYOTI NANDA and JAMES A. ROSS \\ Tissue Injury and Repair Group, Clinical Sciences, Edinburgh Medical School, \\ University of Edinburgh, EH16 4SB Edinburgh, UK
}

Received December 5, 2016; Accepted February 15, 2017

DOI: $10.3892 /$ br.2017.867

\begin{abstract}
Over the past several years, there has been substantial progress in the field of regenerative medicine, which has enabled new possibilities for research and clinical application. For example, there are ongoing efforts directed at generating functional hepatocytes from adult-derived pluripotent cells for toxicity screening, generating disease models or, in the longer term, for the treatment of liver failure. In the present review, the authors summarise recent developments in regenerative medicine and pluripotent stem cells, the methods and tissues used for reprogramming and the differentiation of induced pluripotent stem cells (iPSCs) into hepatocyte-like cells. In addition, the hepatic disease models developed using iPSC technologies are discussed, as well as the potential for gene editing.
\end{abstract}

\section{Contents}

1. Introduction

2. Induced pluripotent stem cells

3. iPS and ES cells, how similar are they?

4. Generating hepatocytes from iPS cells

5. iPSC-derived hepatocyte-like cells for industry and research

6. Discussion

\section{Introduction}

Although modern medicine has made great progress during the last century, there are still few effective ways of treating the root cause of many congenital conditions, diseases and injuries. In many cases, clinicians can only manage the symptoms exhibited by a patient, and there is a requirement for better

Correspondence to: Professor James A. Ross, Tissue Injury and Repair Group, Clinical Sciences, Edinburgh Medical School, University of Edinburgh, Chancellor's Building, 49 Little France Crescent, EH16 4SB Edinburgh, UK

E-mail: j.a.ross@ed.ac.uk

Key words: pluripotent cells, hepatocytes, differentiation and safer drugs for treating such conditions. Methods such as organ transplantation are increasingly unable to meet the needs of patients, due to the lack of sufficient donor organs and issues related to immunocompatability. Regenerative medicine has the potential to revolutionise drug discovery and clinical therapy using stem cells, thereby providing hope for patients with conditions that are currently beyond repair.

Pluripotent stem cells are cells that are capable of generating daughter cells belonging to any of the three embryonic germ layers: The endoderm, mesoderm and ectoderm. The discovery of such cells dates back to the 1960s and 1970s, when researchers identified that the cells of the inner cell mass of the mouse blastocyst were pluripotent in nature $(1,2)$. Further progress followed when Evans and Kaufman (3) and Martin (4) isolated mouse embryonic stem cells (ESCs), and this was further developed by Thomson et al (5) in 1998, who demonstrated a culture of human ESCs isolated from human blastocysts that offered limitless possibilities for regenerative therapy. However, the use of human embryos to generate human ESC lines sparked widespread controversy, restricting the research surrounding the creation of new human ESC lines. Human ESC lines that were already established were later approved for research, yet they were limited in number and lacked the diversity necessary to address many scientific questions. In addition, most of the human ESC lines represented generic genotypes and were not matched to a particular disease or patient (6). The immunological issue of tissue compatibility and the possibility of tumour formation severely restricted their suitability for use in therapy.

In order to capitalise on the potential of these cells, researchers tried to develop personalised pluripotent stem cells by somatic nuclear transfer without fertilisation. Nuclear transfer-generated pluripotent lines would have the complete genome of patients and could be differentiated to specific cell types for cell therapy (7). However, the issues of efficiency, anxiety over artificially-created embryos and the potential use of such cells for human cloning led to criticism, and research in this direction was severely curtailed. In 2006, Takahashi and Yamanaka (8) illustrated how to restore pluripotency in somatic cells through the ectopic co-expression of reprogramming factors, rewriting the fundamental idea on the stability of cellular identity, thereby providing a strategy to create induced pluripotent stem cells (iPSCs). It was a momentous contribution that provided a new direction for research into disease modelling, in vitro differentiation and transdifferentiation, and allowed new hope for the development of personalised therapies. 


\section{Induced pluripotent stem cells}

The last decade has seen rapid development in the field of stem cells with the advent of human ESCs and, more recently, human induced pluripotent stem cells (hiPSCs). Human ESCs and hiPSCs can undergo unlimited self-renewal, retaining their potential to differentiate into any type of somatic cell. This is a significant achievement, as these iPSCs can provide an inexhaustible human cell source (9).

A major advantage of iPSC technology is the ability to generate patient- or disease-specific pluripotent stem cells that can be grown indefinitely in vitro. This is an invaluable resource for medical research, which was previously largely dependent on tumour cell lines or transformed derivatives of adult tissues. hiPSCs from patients with a variety of genetic diseases, such as trisomy 21 syndrome, Parkinson's disease, Huntington disease and type 1 diabetes mellitus have been generated (10). These disease-specific stem cells offer a unique opportunity to study the diseased cells of a tissue in vitro and may aid the development of new drugs for therapeutic intervention.

Advancements in reprogramming technology during the last decade have led to the derivation of many hiPSC lines that can propagate indefinitely. In order to induce pluripotency in somatic cells multiple transcription factors, the most widely used being Oct4, Sox2, Klf4 and c-Myc, require to be transfected into somatic cells. This combination of factors was initially identified by Yamanaka's group through the screening of 24 pre-selected factors in a murine system (11), and later, the same combination of factors was demonstrated to be sufficient for reprogramming human cells $(11,12)$. During reprogramming, DNA methylation and histone modifications occur which induce epigenetic changes in the chromatin structure thereby mimicking the embryonic stage. However, the exact role of transcription factors and their mode of action during reprogramming remain elusive and puzzling. Following Yamanaka's reports $(9,10)$, different groups have now successfully produced hiPSC cells using a variety of starting cell types, different combinations of transcription factors and different delivery techniques of these factors into the cells.

The potential to use of autologous hiPSCs as therapeutic medicines holds tremendous promise. Initially, retroviruses were used to introduce transcription factor genes into the nucleus of somatic cells. Retroviral methods require proliferating cells and have poor transfection efficiency. The major disadvantage of the retroviral technique is the potential to simultaneously introduce insertional mutations into the genome and, thereby, promote tumour formation. This drawback shifted the attention of researchers to explore the use of other techniques for the insertion of genes, such as lentiviral and adenoviral vectors. Lentiviruses can infect non-proliferating cells, and can integrate into the genome of the target cell, without expressing viral genes $(13,14)$. However, the limited insertion size, difficulty in storage/quality control and safety concerns of using virus is the primary drawbacks of using this system. Conversely, adenoviral vectors allow transient, high-level expression of exogenous genes without integrating into the host genome (15). Adenoviruses have been used to generate iPSCs from mouse fibroblasts and liver cells (16). Liver cells are highly permissive for adenoviral infections and, therefore, less adenovirus is required for the efficient reprogramming of liver cells compared with fibroblasts. However, the continuous expression of transgenes in iPSCs can limit their differentiation potential (17). Many studies have explored the removal of viral vectors after reprogramming. These techniques include plasmid transfection and piggyback transposition system, in which the inserted transgene can be subsequently excised to remove the risk of residual expression and re-activation of reprogramming factors $(18,19)$. The risk of insertional mutagenesis still remains, as the sequences beyond the Lox site cannot be fully excised.

Recently, there have been many studies to identify alternatives to viral vectors for reprogramming somatic cells. Among them, the technologies that do not require genome integration appear more promising. These technologies include the use of small chemical molecules (20), episomal vectors (21), recombinant proteins (22), microRNAs (23) and synthetic modified mRNAs (24). Owing to its high reproducibility and simplicity, the transient transfection technique seems promising and may find widespread application.

In addition, different tissue sources have been considered for generating iPSCs. Due to the ease of isolation and maintenance for reprogramming, the most popular source is fibroblasts. Other cell types, including keratinocytes (25), mesenchymal stem cells (26), adipose stem cells (27), hair follicular cells (28), neural stem cells (29) and urinary cells (30), have also been used successfully. A more desirable source of starting material is human peripheral blood, which can be readily obtained through non-invasive routine clinical procedures. However, the non-adherent nature of most blood cells complicates the process of reprogramming. Recently, a robust method for reprogramming peripheral blood mononuclear cells using a non-viral, feeder cell-free methodology has been developed (21).

\section{3. iPS and ES cells, how similar are they?}

Even though iPSCs possess phenotypic and behavioural similarity to ESCs, recent critical analysis of their genetics and epigenetics demonstrates that iPSCs can carry residual DNA methylation patterns from their source tissue $(31,32)$. Transcribed genes and mutational load have demonstrated small distinctive dissimilarities between iPS and ES cells (33), and this epigenetic memory can favour the differentiation of iPS cells towards the parental cell type. However, this phenomenon appears to be transitory in many lines and, in some instances, can be erased by additional reprogramming, by chromatin-modifying drugs, or with extended passaging of the cells (34). Differences in endogenous signalling activity may also contribute to the heterogeneity of iPSC lines generated from the same tissue sample (35). A recent study on variation between pluripotent cell lines indicates that a difference in genetic background is the major factor for variation, rather than aberrations arising during viral transfection (36). In the authors' experience, extended passaging of iPSC lines did not promote differences in hepatic differentiation, irrespective of the parental tissue of origin. However, previous work of the University of Edinburgh has observed that iPSCs generated using episomal vectors are able to produce healthy hepatocyte-like cells comparable to those produced with lentiviral or Sendai vector systems (21). 
Table I. Protocols used to generate hepatic differentiation (3 stage methods).

\begin{tabular}{|c|c|c|c|c|}
\hline & Signalling molecules & $\begin{array}{l}\text { Duration } \\
\text { (days) }\end{array}$ & Markers & Refs. \\
\hline \multirow[t]{9}{*}{$\begin{array}{l}\text { Definitive endoderm } \\
\text { differentiation }\end{array}$} & $\begin{array}{l}100 \mathrm{ng} / \mathrm{ml} \text { Activin } \mathrm{A}, 10 \mu \mathrm{M} \\
\mathrm{LY} 294002 \text { (inhibit insulin, } \\
\mathrm{PI} 3 \mathrm{~K} / \mathrm{AKT} \text { pathway) } \\
2 \mu \mathrm{M} \text { bromo-indirubin-3'-oxime } \\
\text { (mimic Wnt signalling) }\end{array}$ & 6 & FOXA2, SOX17 & $(53)$ \\
\hline & $100 \mathrm{ng} / \mathrm{ml}$ Activin A, $50 \mathrm{ng} / \mathrm{ml} \mathrm{Wnt3A}$ & 3 & FOXA2, SOX17 & $(46,53,54)$ \\
\hline & $\begin{array}{l}3 \mu \mathrm{M} \text { CHIR99021(mimic } \\
\text { Wnt signalling) }\end{array}$ & 1 & FOXA2, SOX17, & $(55)$ \\
\hline & followed by medium alone & 1 & HHEX, GATA4 & \\
\hline & $\begin{array}{l}100 \mathrm{ng} / \mathrm{ml} \text { Activin A, } 100 \mathrm{ng} / \mathrm{ml} \mathrm{bFGF} \text {, } \\
10 \mathrm{ng} / \mathrm{ml} \text { BMP4, } 10 \mu \mathrm{M} \text { LY294002, } \\
3 \mu \mathrm{M} \mathrm{CHIR} 99021 \text { (only for } 24 \mathrm{~h} \text { ) } \\
\text { followed by } 100 \mathrm{ng} / \mathrm{ml} \text { Activin A, } \\
100 \mathrm{ng} / \mathrm{ml} \mathrm{bFGF-1} \mathrm{day} \\
\text { and } 50 \mathrm{ng} / \mathrm{ml} \text { Activin A }\end{array}$ & 2 & $\begin{array}{l}\text { SOX17, FOXA2 } \\
\text { and HHEX }\end{array}$ & $(56)$ \\
\hline & $\begin{array}{l}2 \mu \mathrm{g} / \mathrm{ml} \mathrm{CHIR} 99021 \text { and } \\
100 \mathrm{ng} / \mathrm{ml} \text { Activin A }\end{array}$ & 1 & $\begin{array}{l}\text { CXCR4, Ckit, } \\
\text { SOX17, FOXA1 }\end{array}$ & $(57)$ \\
\hline & 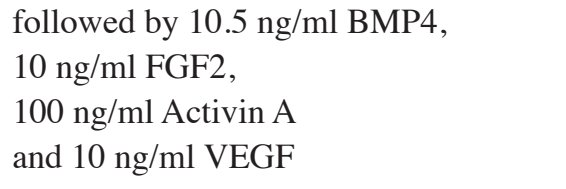 & 4 & & \\
\hline & 100 ng/ml Activin A & 6 & HNF3B, CXCR4 & $(58)$ \\
\hline & 100 ng/ml Activin A & 5 & $\begin{array}{l}\text { GATA } 4, \text { SOX17, } \\
\text { FOXA2 }\end{array}$ & $(59)$ \\
\hline \multirow[t]{8}{*}{ Hepatoblast } & $\begin{array}{l}250 \mathrm{nM} \text { sodium butyrate } \\
\text { and } 0.5 \% \mathrm{DMSO}\end{array}$ & $6-8$ & $\begin{array}{l}\text { FOXA2, AFP, ALB, } \\
\text { HNF4A, CK18, CK19 }\end{array}$ & $(53)$ \\
\hline & $10 \mathrm{ng} / \mathrm{ml} \mathrm{FGF-2} \mathrm{and} 50 \mathrm{ng} / \mathrm{ml}$ BMP-4 & 4 & FOXA2, AFP, ALB, & $(53,54)$ \\
\hline & $\begin{array}{l}\text { followed by } 50 \mathrm{ng} / \mathrm{ml} \text { FGF1, } \\
10 \mathrm{ng} / \mathrm{ml} \mathrm{FGF} 4 \text { and } 25 \mathrm{ng} / \mathrm{ml} \mathrm{FGF8b}\end{array}$ & 4 & HNF4A, CK18, CK19, & \\
\hline & $1 \%$ DMSO & 5 & $\begin{array}{l}\text { AFP, CEBPA, FOXA2, } \\
\text { GATA4, HNF4A } \\
\text { PROX1, TBX3, TTR }\end{array}$ & $(46,55)$ \\
\hline & 20 ng/ml BMP4, 10 ng/ml FGF10 & 4 & $\begin{array}{l}\text { HNF4A, PROX1, } \\
\text { HHEX, AFP, TBX3, } \\
\text { FOXA2, AFP, ALB }\end{array}$ & $(56)$ \\
\hline & $\begin{array}{l}50 \mathrm{ng} / \mathrm{ml} \mathrm{BMP} 4,10 \mathrm{ng} / \mathrm{ml} \mathrm{FGF} 2 \text {, } \\
10 \mathrm{ng} / \mathrm{ml} \mathrm{VEGF}, 10 \mathrm{ng} / \mathrm{ml} \mathrm{EGF} \text {, } \\
20 \mathrm{ng} / \mathrm{ml} \mathrm{TGF} \alpha, 100 \mathrm{ng} / \mathrm{ml} \mathrm{HGF} \\
\text { and } 0.1 \mu \mathrm{M} \text { Dex }\end{array}$ & 6 & FOXA2, AFP, ALB & $(57)$ \\
\hline & $\begin{array}{l}5 \mathrm{ng} / \mathrm{ml} \mathrm{FGF4,10} \mathrm{ng/ml} \mathrm{BMP2,} \\
5 \mathrm{ng} / \mathrm{ml} \mathrm{FGF4,10} \mathrm{ng/ml} \mathrm{BMP2,} \\
10 \mathrm{ng} / \mathrm{ml} \mathrm{BMP4}\end{array}$ & 4 & HNF4A & $(58)$ \\
\hline & $\begin{array}{l}20 \mathrm{ng} / \mathrm{ml} \mathrm{BMP} 4,10 \mathrm{ng} / \mathrm{ml} \mathrm{FGF} 2 \\
\text { followed by } 20 \mathrm{ng} / \mathrm{ml} \mathrm{HGF}\end{array}$ & $\begin{array}{c}5 \\
5(\text { at } 4 \% \\
\left.\mathrm{O}_{2}\right)\end{array}$ & FOXA2, HNF4A, AFP & $(59)$ \\
\hline \multirow[t]{3}{*}{ Hepatic maturation } & $1 \mu \mathrm{M} \mathrm{SB} 431542$ and $1 \%$ DMSO & 8 & $\begin{array}{l}\text { ALB, A1AT, ASGPR, } \\
\text { MRP2, CYP3A4, } \\
\text { CYP1A1, CYP1A2, urea }\end{array}$ & $(53)$ \\
\hline & $\begin{array}{l}20 \mathrm{ng} / \mathrm{ml} \mathrm{HGF} \text { and } \\
100 \mathrm{ng} / \mathrm{ml} \text { Follistatin }\end{array}$ & 6 & $\begin{array}{l}\text { ALB, A1AT, ASGPR, } \\
\text { MRP2, CYP3A4, CYP1A1, }\end{array}$ & $(53,54)$ \\
\hline & 100 nM DiHexa, 100 nM Dex & 10 & $\begin{array}{l}\text { ALB, HNF4A, A1AT, CYP3A4, } \\
\text { CYP1A2, Fibronectin }\end{array}$ & $(55)$ \\
\hline
\end{tabular}


Table I. Continued.

\begin{tabular}{|c|c|c|c|c|}
\hline & Signalling molecules & $\begin{array}{l}\text { Duration } \\
\text { (days) }\end{array}$ & Markers & Refs. \\
\hline \multirow[t]{9}{*}{ Hepatic maturation } & $\begin{array}{l}100 \mathrm{ng} / \mathrm{ml} \mathrm{HGF}, 20 \mathrm{ng} / \mathrm{ml} \text { OSM, } \\
10 \mu \mathrm{M} \mathrm{HC}\end{array}$ & $18-20$ & $\begin{array}{l}\text { ALB, ECAD, CYP3A4, } \\
\text { CYP2D6, MRP1, HNF4A }\end{array}$ & $(46)$ \\
\hline & $50 \mathrm{ng} / \mathrm{ml} \mathrm{HGF}, 30 \mathrm{ng} / \mathrm{ml}$ OSM & 15 & $\begin{array}{l}\text { ALB, CK18, A1AT, } \\
\text { CYP3A4, LDL uptake, } \\
\text { TAT, TTR }\end{array}$ & $(56)$ \\
\hline & $\begin{array}{l}10 \mathrm{ng} / \mathrm{ml} \text { FGF2, } 10 \mathrm{ng} / \mathrm{ml} \text { VEGF, } \\
10 \mathrm{ng} / \mathrm{ml} \text { EGF, } 100 \mathrm{ng} / \mathrm{ml} \mathrm{HGF} \text {, } \\
1.5 \mu \mathrm{M} \gamma \text { secretase inhibitor, } \\
0.1 \mu \mathrm{M} \text { Dex, } 1 \% \text { DMSO }\end{array}$ & 6 & $\begin{array}{l}\text { A1AT, ALB, AFP, TTR, } \\
\text { fibronectin, transferrin, } \\
\text { CYP450 }\end{array}$ & $(56)$ \\
\hline & followed by & 6 & & \\
\hline & $100 \mathrm{ng} / \mathrm{ml} \mathrm{HGF}, 20 \mathrm{ng} / \mathrm{ml}$ OSM & & & \\
\hline & $6 \mu \mathrm{g} / \mathrm{ml}$ Vitamin $\mathrm{K}, 0.1 \mu \mathrm{M}$ Dex & & & \\
\hline & $\begin{array}{l}10 \mathrm{ng} / \mathrm{ml} \text { HGF, } 10 \mathrm{ng} / \mathrm{ml} \text { OSM, } \\
0.1 \mu \mathrm{M} \text { Dex }\end{array}$ & 6 & $\begin{array}{l}\text { ALB, AAT, CK19, } \\
\text { CK8, CK18, AFP, }\end{array}$ & $(58)$ \\
\hline & followed by $0.1 \mu \mathrm{M}$ Dex & 5 & CYP3A4, CYP1A2 & \\
\hline & $20 \mathrm{ng} / \mathrm{ml} \mathrm{OSM}$ & 5 & $\begin{array}{l}\text { ALB, AFP, HNF4A, } \\
\text { FOXA2 }\end{array}$ & $(59)$ \\
\hline
\end{tabular}

bFGF, basic fibroblast growth factor; FGF, fibroblast growth factor; BMP, bone morphogenetic protein; VEGF, vasculalr endothelial growth factor; DMSO, dimethyl sulfoxide; EGF, epidermal growth factor; TGF- $\alpha$, transforming growth factor- $\alpha$; HGF, hepatocyte growth factor; Dex, dexamethasone; DiHexa, N-hexanoic-Tyr-Ile-(6) aminohexanoicamide; OSM, oncostatin M; HC, hydrocortisone.

\section{Generating hepatocytes from iPS cells}

Under in vivo conditions, stem cells undergo a complex set of chemical interactions, switching on or off of various signalling molecules, cell-cell and cell-ECM interactions, during the process of becoming terminally differentiated cells. It is difficult to mimic many of these cues under experimental conditions. Some cell types, such as cardiomyocytes, develop spontaneously in stem cell culture (at low frequency) while other cell types, such as hepatocytes and renal tubular cells, require significant technical manoeuvres. Pluripotent stem cells certainly appear to progress more efficiently than mesenchymal stem cells toward a hepatocyte fate (37).

During embryogenesis, Nodal and Wnt signalling triggers endoderm development. Later on in the differentiation process, the switching on or off of this signalling regulates endodermal tube patterning $(34,35)$. Mesodermal cells surrounding the endoderm tube are involved in the hepatic commitment of foregut cells (mainly through fibroblast growth factor and bone morphogenetic protein signalling) and liver bud formation. Later, endothelial cells colonise the liver bud and hepatoblasts start to differentiate to biliary cells (hepatoblasts near the portal vein) and hepatocytes $(38,39)$.

Researchers have tried to differentiate pluripotent stem cells in cell aggregates or as a monolayer. Pluripotent stem cells can be aggregated to form embryoid bodies and can be differentiated by exposure to specific cytokine and growth factor cocktails (40). However, all the existing embryoid body-based protocols suffer from low differentiation efficiency and spontaneous differentiation which gives rise to unwanted cell lineages (41-43). As monolayer culture can be adjusted to avoid most of these issues, it has been utilised widely and is capable of producing relatively pure populations of cells with hepatic function. Among the different approaches used to generate hepatocyte-like cells as monolayers, methods mimicking the embryonic developmental stages of the liver seem to be the more promising (Table I). Unfortunately, the outcome of such approaches varies between different research groups for a variety of reasons, including variation in cell lines and the conditions used for culture. Efforts have been made to optimise the protocol by eliminating the use of poorly defined components such as serum, feeder cells, undefined culture medium and extracellular matrix to promote consistent results (44-46). A key to the success of these protocols is the ability to generate definitive endoderm cells with high efficiency, mainly by using activin A and Wnt $3 \mathrm{~A}(47,48)$, and this approach has yielded functionally improved hepatocyte-like cells. Efforts to differentiate iPS cells under 3D dynamic environments also helped to enhance the function, but were also more like foetal hepatocytes and lacked maturity (49).

Stem cell-derived hepatocytes have been reported to express phase I and II metabolising enzymes, hepatic morphology and polarisation, but are still not comparable to primary hepatocytes. Hepatic differentiation protocols, evaluation strategies and phenotypic or functional outcomes vary widely between different laboratories (50). A direct comparison of the efficiency of pluripotent stem cell lines to generate functional hepatocytes is therefore difficult. As a general observation, hiPSC lines present more variable hepatocyte differentiation and performance compared with ESC lines, 
particularly the H9 line. This may be due to the fact that the available differentiation protocols have been developed with ESC lines, and these protocols do not address the potential retained epigenetic memory or aberrations that iPSC lines may possess, making certain that iPSC lines respond weakly to hepatic differentiation signals. Moreover, in vitro culture itself can induce aberrations in pluripotent cells, and can result in significant changes in the differentiation potential within different passages of the same cell line $(51,52)$.

\section{5. iPSC-derived hepatocyte-like cells for industry and research}

The pharmaceutical industries are, at present, reliant primarily on animal tests to establish the safety of any new products. These tests often fail to predict human toxicity accurately due to the physiological differences between humans and animals. The advent of iPSCs have offered a new opportunities and one would anticipate that in the near future it will be possible to perform toxicity screens using iPSC-derived healthy or diseased cells where safety, efficacy, dosage studies and the effect of genetics could be studied in human cells before a clinical trial.

Severe perturbance in key proteins of metabolic pathways can upset hepatocyte homeostasis and can promote liver disease (60). Using iPSC technology, it is now possible to study, at the cellular level, the pathobiology of genetic liver diseases under in vitro conditions. Disease-specific hiPSCs of $\alpha 1$-antitrypsin deficiency, familial hypercholesterolemia and glycogen storage disease type 1a generated from patients presented key pathological features of the diseases in in vitro culture (61). A later study from the same group demonstrated that genetic correction of an $\alpha 1$-antitrypsin-deficient iPSC line by gene editing could restore the structure and function of $\alpha 1$-antitrypsin in the derived hepatocytes both in vitro and in vivo (62), providing hope for future gene therapy. A number of iPSC lines from patients suffering from tyrosinemia, glycogen storage disease, progressive familial hereditary cholestasis and Crigler-Najjar syndrome have also been generated successfully (63). Wilson's disease-specific iPSC lines with the R778L hotspot mutation in the ATP7B gene were able to produce hepatocytes with defective copper transport in culture (64). The modelling of other inherited diseases, such as hemochromatosis, hepatobiliary cystic fibrosis and idiosyncratic drug reactions would be helpful for understanding the respective disease processes and devising clinical interventions. In relation to this, the gene editing of iPS cells, not only to correct mutations (62), but also to introduce mutations of interest, is an important development in disease modelling. Of particular interest in this regard is the developing use of CRISPR technology in iPSCs to edit genes involved in drug metabolism, thereby providing in vitro models relevant to drug development.

\section{Discussion}

Although significant progress has been made in iPSC technology, a full adoption of iPSC-derived hepatocytes by industry will require more robust, consistent and cost effective protocols, scale-up and comparative studies with primary hepatocytes (65). At present, the state-of-the-art hepatic differentiation protocols produce cells, which are foetal in both phenotype and function (66). There remains insufficient data demonstrating that iPSC-derived hepatocyte-like cells are comparable to existing primary hepatocyte systems or hepatic cell lines, although improved protocols for generating hepatocytes are progressing rapidly. Following the establishment of improved hepatocyte differentiation protocols, the technology for cost-effective scale-up conditions that can maintain phenotype, function, batch-to-batch consistency and reproducibility will be required. Given the intensive ongoing research efforts, iPSCs will soon be utilised for generating highly predictable human hepatic cells of use in determining drug safety, as well as for studying the mechanism of action of drugs or small molecules and for the generation of new cellular disease models.

\section{Acknowledgements}

The present study is supported by the Innovative Medicines Initiative Joint Undertaking (grant no. 115439), resources of which are composed of financial contribution from the European Union's Seventh Framework Programme (grant no. FP7/2007-2013) and EFPIA companies in kind contribution. This publication reflects only the author's views and neither the IMI JU nor EFPIA, nor the European Commission, are liable for any use that may be made of the information contained therein.

\section{References}

1. Kleinsmith LJ and Pierce GB Jr: Multipotentiality of single embryonal carcinoma cells. Cancer Res 24: 1544-1551, 1964.

2. Rosenthal MD, Wishnow RM and Sato GH: In vitro growth and differetiation of clonal populations of multipotential mouse clls derived from a transplantable testicular teratocarcinoma. J Natl Cancer Inst 44: 1001-1014, 1970.

3. Evans MJ and Kaufman MH: Establishment in culture of pluripotential cells from mouse embryos. Nature 292: 154-156, 1981.

4. Martin GR: Isolation of a pluripotent cell line from early mouse embryos cultured in medium conditioned by teratocarcinoma stem cells. Proc Natl Acad Sci USA 78: 7634-7638, 1981.

5. Thomson JA, Itskovitz-Eldor J, Shapiro SS, et al: Embryonic stem cell lines derived from human blastocysts. Science 282: 1145-1147, 1998

6. Mosher JT, Pemberton TJ, Harter K, Wang C, Buzbas EO, Dvorak P, Simón C, Morrison SJ and Rosenberg NA: Lack of population diversity in commonly used human embryonic stem-cell lines. N Engl J Med 362: 183-185, 2010.

7. Tabar V, Tomishima M, Panagiotakos G, Wakayama S, Menon J Chan B, Mizutani E, Al-Shamy G, Ohta H, Wakayama T and Studer L: Therapeutic cloning in individual parkinsonian mice. Nat Med 14: 379-381, 2008

8. Takahashi $\mathrm{K}$ and Yamanaka S: Induction of pluripotent stem cells from mouse embryonic and adult fibroblast cultures by defined factors. Cell 126: 663-676, 2006.

9. Palakkan AA, Hay DC, Anil Kumar PR, Kumary TV and Ross JA: Liver tissue engineering and cell sources: Issues and challenges. Liver Int 33: 666-676, 2013.

10. Park IH, Arora N, Huo H, Maherali N, Ahfeldt T, Shimamura A, Lensch MW, Cowan C, Hochedlinger K and Daley GQ: Disease-specific induced pluripotent stem cells. Cell 134: 877-886, 2008.

11. Kastenberg ZJ and Odorico JS: Alternative sources of pluripotency: Science, ethics, and stem cells. Transplant Rev (Orlando) 22: 215-222, 2008.

12. Park IH, Zhao R, West JA, Yabuuchi A, Huo H, Ince TA, Lerou PH, Lensch MW and Daley GQ: Reprogramming of human somatic cells to pluripotency with defined factors. Nature 451: 141-146, 2008. 
13. Montini E, Cesana D, Schmidt M, Sanvito F, Ponzoni M, Bartholomae C, Sergi Sergi L, Benedicenti F, Ambrosi A, Di Serio C, et al: Hematopoietic stem cell gene transfer in a tumor-prone mouse model uncovers low genotoxicity of lentiviral vector integration. Nat Biotechnol 24: 687-696, 2006.

14. Cattoglio C, Facchini G, Sartori D, Antonelli A, Miccio A, Cassani B, Schmidt M, von Kalle C, Howe S, Thrasher AJ, et al: Hot spots of retroviral integration in human $\mathrm{CD} 34^{+}$hematopoietic cells. Blood 110: 1770-1778, 2007.

15. Okita K, Nakagawa M, Hyenjong H, Ichisaka T and Yamanaka S: Generation of mouse induced pluripotent stem cells without viral vectors. Science 322: 949-953, 2008.

16. Stadtfeld M, Nagaya M, Utikal J, Weir G and Hochedlinger K: Induced pluripotent stem cells generated without viral integration. Science 322: 945-949, 2008.

17. Sommer CA, Sommer AG, Longmire TA, Christodoulou C, Thomas DD, Gostissa M, Alt FW, Murphy GJ, Kotton DN and Mostoslavsky G: Excision of reprogramming transgenes improves the differentiation potential of iPS cells generated with a single excisable vector. Stem Cells 28: 64-74, 2010.

18. Karow M, Chavez CL, Farruggio AP, Geisinger JM, Keravala A, Jung WE, Lan F, Wu JC, Chen-Tsai Y and Calos MP: Site-specific recombinase strategy to create induced pluripotent stem cells efficiently with plasmid DNA. Stem Cells 29: 1696-1704, 2011.

19. Loh YH, Yang JC, De Los Angeles A, Guo C, Cherry A, Rossi DJ, Park IH and Daley GQ: Excision of a viral reprogramming cassette by delivery of synthetic Cre mRNA. Curr Protoc Stem Cell Biol 5, 2012.

20. Solanki A and Lee KB: A step closer to complete chemical reprogramming for generating iPS cells. ChemBioChem 11: 755-757, 2010.

21. Liu J, Brzeszczynska J, Samuel K, Black J, Palakkan A, Anderson RA, Gallagher R and Ross JA: Efficient episomal reprogramming of blood mononuclear cells and differentiation to hepatocytes with functional drug metabolism. Exp Cell Res 338 203-213, 2015

22. Kim D, Kim CH, Moon JI, Chung YG, Chang MY, Han BS, Ko S, Yang E, Cha KY, Lanza R and Kim KS: Generation of human induced pluripotent stem cells by direct delivery of reprogramming proteins. Cell Stem Cell 4: 472-476, 2009.

23. Miyoshi N, Ishii H, Nagano H, Haraguchi N, Dewi DL, Kano Y, Nishikawa S, Tanemura M, Mimori K, Tanaka F, et al: Reprogramming of mouse and human cells to pluripotency using mature microRNAs. Cell Stem Cell 8: 633-638, 2011

24. Warren L, Manos PD, Ahfeldt T, Loh YH, Li H, Lau F, Ebina W, Mandal PK, Smith ZD, Meissner A, et al: Highly efficient reprogramming to pluripotency and directed differentiation of human cells with synthetic modified mRNA. Cell Stem Cell 7: 618-630, 2010.

25. Piao Y, Hung SS, Lim SY, Wong RC and Ko MS: Efficient generation of integration-free human induced pluripotent stem cells from keratinocytes by simple transfection of episomal vectors. Stem Cells Transl Med 3: 787-791, 2014.

26. Diederichs S and Tuan RS: Functional comparison of human-induced pluripotent stem cell-derived mesenchymal cells and bone marrow-derived mesenchymal stromal cells from the same donor. Stem Cells Dev 23: 1594-1610, 2014.

27. Chen MJ, Lu Y, Hamazaki T, Tsai HY, Erger K, Conlon T, Elshikha AS, Li H, Srivastava A, Yao C, et al: Reprogramming adipose tissue-derived mesenchymal stem cells into pluripoten stem cells by a mutant adeno-associated viral vector. Hum Gene Ther Methods 25: 72-82, 2014.

28. Wang Y, Liu J, Tan X, Li G, Gao Y, Liu X, Zhang L and Li Y: Induced pluripotent stem cells from human hair follicle mesenchymal stem cells. Stem Cell Rev 9: 451-460, 2013.

29. Kim JB, Zaehres H, Wu G, Gentile L, Ko K, Sebastiano V, Araúzo-Bravo MJ, Ruau D, Han DW, Zenke M and Schöler HR Pluripotent stem cells induced from adult neural stem cells by reprogramming with two factors. Nature 454: 646-650, 2008.

30. Zhou T, Benda C, Dunzinger S, Huang Y, Ho JC, Yang J, Wang Y, Zhang Y, Zhuang Q, Li Y, et al: Generation of human induced pluripotent stem cells from urine samples. Nat Protoc 7: 2080-2089, 2012.

31. Kim K, Doi A, Wen B, Ng K, Zhao R, Cahan P, Kim J, Aryee MJ, $\mathrm{Ji} \mathrm{H}$, Ehrlich LI, et al: Epigenetic memory in induced pluripotent stem cells. Nature 467: 285-290, 2010.

32. Ohi Y, Qin H, Hong C, Blouin L, Polo JM, Guo T, QiZ, Downey SL, Manos PD, Rossi DJ, et al: Incomplete DNA methylation underlies a transcriptional memory of somatic cells in human iPS cells. Nat Cell Biol 13: 541-549, 2011.
33. Bilic J and Izpisua Belmonte JC: Concise review: Induced pluripotent stem cells versus embryonic stem cells: close enough or yet too far apart? Stem Cells 30: 33-41, 2012.

34. Kim K, Zhao R, Doi A, Ng K, Unternaehrer J, Cahan P, Huo H, Loh YH, Aryee MJ, Lensch MW, et al: Donor cell type can influence the epigenome and differentiation potential of human induced pluripotent stem cells. Nat Biotechnol 29: 1117-1119, 2011.

35. Blauwkamp TA, Nigam S, Ardehali R, Weissman IL and Nusse R: Endogenous Wnt signalling in human embryonic stem cells generates an equilibrium of distinct lineage-specified progenitors. Nat Commun 3: 1070, 2012.

36. Choi J, Lee S, Mallard W, Clement K, Tagliazucchi GM, Lim H, Choi IY, Ferrari F, Tsankov AM, Pop R, et al: A comparison of genetically matched cell lines reveals the equivalence of human iPSCs and ESCs. Nat Biotechnol 33: 1173-1181, 2015.

37. Palakkan AA, Drummond R, Anderson RA, Greenhough S, Tv K, Hay DC and Ross JA: Polarisation and functional characterisation of hepatocytes derived from human embryonic and mesenchymal stem cells. Biomed Rep 3: 626-636, 2015.

38. Zhao R and Duncan SA: Embryonic development of the liver. Hepatology 41: 956-967, 2005.

39. Zorn AM: Liver development. Stembook, 2008. https://doi. org/10.3824/stembook.1.25.1.

40. Schwartz RE, Linehan JL, Painschab MS, Hu WS, Verfaillie CM and Kaufman DS: Defined conditions for development of functional hepatic cells from human embryonic stem cells. Stem Cells Dev 14: 643-655, 2005.

41. Greenhough S, Bradburn H, Gardner J and Hay DC: Development of an embryoid body-based screening strategy for assessing the hepatocyte differentiation potential of human embryonic stem cells following single-cell dissociation. Cell Reprogram 15: 9-14, 2013.

42. Asahina K,FujimoriH,Shimizu-Saito K, Kumashiro Y,Okamura K, Tanaka Y, Teramoto K, Arii S and Teraoka H: Expression of the liver-specific gene Cyp7a1 reveals hepatic differentiation in embryoid bodies derived from mouse embryonic stem cells. Genes Cells 9: 1297-1308, 2004.

43. Carpenedo RL, Seaman SA and McDevitt TC: Microsphere size effects on embryoid body incorporation and embryonic stem cell differentiation. J Biomed Mater Res A 94: 466-475, 2010

44. Cameron K, Lucendo-Villarin B, Szkolnicka D and Hay DC: Serum-free directed differentiation of human embryonic stem cells to hepatocytes. Methods Mol Biol 1250: 105-111, 2015.

45. Villarin BL, Cameron K, Szkolnicka D, Rashidi H, Bates N, Kimber SJ, Flint O, Forbes SJ, Iredale JP, Bradley $M$ and Hay DC: Polyurethane: Stable cell phenotype requires plasticity: Polymer supported directed differentiation reveals a unique gene signature predicting stable hepatocyte performance. Adv Healthc Mater 4: 1820-1825, 2015.

46. Cameron K, Tan R, Schmidt-Heck W, Campos G, Lyall MJ, Wang Y, Lucendo-Villarin B, Szkolnicka D, Bates N, Kimber SJ, et al: Recombinant laminins drive the differentiation and self-organization of hESC-derived hepatocytes. Stem Cell Reports 5: 1250-1262, 2015

47. D'Amour KA, Agulnick AD, Eliazer S, Kelly OG, Kroon E and Baetge EE: Efficient differentiation of human embryonic stem cells to definitive endoderm. Nat Biotechnol 23: 1534-1541, 2005.

48. Hay DC, Fletcher J, Payne C, Terrace JD, Gallagher RC, Snoeys J, Black JR, Wojtacha D, Samuel K, Hannoun Z, et al: Highly efficient differentiation of hESCs to functional hepatic endoderm requires ActivinA and Wnt3a signaling. Proc Nat Acad Sci USA 105: 12301-12306, 2008.

49. Leclerc E, Kimura K, Shinohara M, Danoy M, Le Gall M, Kido T, Miyajima A, Fujii T and Sakai Y: Comparison of the transcriptomic profile of hepatic human induced pluripotent stem like cells cultured in plates and in a 3D microscale dynamic environment. Genomics 109: 16-26, 2017.

50. Godoy P, Schmidt-Heck W, Natarajan K, Lucendo-Villarin B, Szkolnicka D, Asplund A, Björquist P, Widera A, Stöber R, Campos G, et al: Gene networks and transcription factor motifs defining the differentiation of stem cells into hepatocyte-like cells. J Hepatol 63: 934-942, 2015.

51. Osafune K, Caron L, Borowiak M, Martinez RJ, Fitz-Gerald CS, Sato Y, Cowan CA, Chien KR and Melton DA: Marked differences in differentiation propensity among human embryonic stem cell lines. Nat Biotechnol 26: 313-315, 2008.

52. Chang KH, Nelson AM, Fields PA, Hesson JL, Ulyanova T, Cao H, Nakamoto B, Ware CB and Papayannopoulou T: Diverse hematopoietic potentials of five human embryonic stem cell lines. Exp Cell Res 314: 2930-2940, 2008. 
53. Tasnim F, Phan D, Toh YC and Yu H: Cost-effective differentiation of hepatocyte-like cells from human pluripotent stem cells using small molecules. Biomaterials 70: 115-125, 2015.

54. Roelandt P, Pauwelyn KA, Sancho-Bru P, Subramanian K, Bose B, Ordovas L, Vanuytsel K, Geraerts M, Firpo M, De Vos R, et al: Human embryonic and rat adult stem cells with primitive endoderm-like phenotype can be fated to definitive endoderm, and finally hepatocyte-like cells. PLoS One 5: e12101, 2010.

55. Siller R, Greenhough S, Naumovska E and Sullivan GJ: Small-molecule-driven hepatocyte differentiation of human pluripotent stem cells. Stem Cell Reports 4: 939-952, 2015.

56. Hannan NR, Segeritz CP, Touboul T and Vallier L: Production of hepatocyte-like cells from human pluripotent stem cells. Nat Protoc 8: 430-437, 2013.

57. Wilson AA, Ying L, Liesa M, Segeritz CP, Mills JA, Shen SS Jean J, Lonza GC, Liberti DC, Lang AH, et al: Emergence of a stage-dependent human liver disease signature with directed differentiation of alpha-1 antitrypsin-deficient iPS cells. Stem Cell Reports 4: 873-885, 2015.

58. Kanninen LK, Harjumäki R, Peltoniemi P, Bogacheva MS, Salmi T, Porola P, Niklander J, Smutný T, Urtti A, Yliperttula ML, Lou YR: Laminin-511 and laminin-521-based matrices for efficient hepatic specification of human pluripotent stem cells. Biomaterials 103: 86-100, 2016.

59. Si-Tayeb K, Noto FK, Nagaoka M, Li J, Battle MA, Duris C, North PE, Dalton S and Duncan SA: Highly efficient generation of human hepatocyte-like cells from induced pluripotent stem cells. Hepatology 51: 297-305, 2010

60. Pietrangelo A: Inherited metabolic disease of the liver. Curr Opin Gastroenterol 25: 209-214, 2009.
61. Rashid ST, Corbineau S, Hannan N, Marciniak SJ, Miranda E, Alexander G, Huang-Doran I, Griffin J, Ahrlund-Richter L, Skepper J, et al: Modeling inherited metabolic disorders of the liver using human induced pluripotent stem cells. J Clin Invest 120: 3127-3136, 2010.

62. Yusa K, Rashid ST, Strick-Marchand H, Varela I, Liu PQ, Paschon DE, Miranda E, Ordóñez A, Hannan NR, Rouhani FJ, et al: Targeted gene correction of $\alpha 1$-antitrypsin deficiency in induced pluripotent stem cells. Nature 478: 391-394, 2011.

63. Ghodsizadeh A, Taei A, Totonchi M, Seifinejad A, Gourabi H, Pournasr B, Aghdami N, Malekzadeh R, Almadani N, Salekdeh GH, et al: Generation of liver disease-specific induced pluripotent stem cells along with efficient differentiation to functional hepatocyte-like cells. Stem Cell Rev 6: 622-632, 2010.

64. Zhang S, Chen S, Li W, Guo X, Zhao P, Xu J, Chen Y, Pan Q, Liu X, Zychlinski D, et al: Rescue of ATP7B function in hepatocyte-like cells from Wilson's disease induced pluripotent stem cells using gene therapy or the chaperone drug curcumin. Hum Mol Genet 20: 3176-3187, 2011.

65. Goldring C, Antoine DJ, Bonner F, Crozier J, Denning C, Fontana RJ, Hanley NA, Hay DC, Ingelman-Sundberg M, Juhila $\mathrm{S}$, et al: Stem cell-derived models to improve mechanistic understanding and prediction of human drug-induced liver injury. Hepatology 65: 710-721, 2017.

66. Baxter M, Withey S, Harrison S, Segeritz CP, Zhang F, Atkinson-Dell R, Rowe C, Gerrard DT, Sison-Young R, Jenkins R, et al: Phenotypic and functional analyses show stem cell-derived hepatocyte-like cells better mimic fetal rather than adult hepatocytes. J Hepatol 62: 581-589, 2015 